\title{
Effect of dietary supplementation of herbal seeds on carcass traits of turkey poults
}

\author{
Darshana B. Bhaisare ${ }^{1}$, D. Thyagarajan², R. Richard Churchil ${ }^{3}$ and N. Punniamurthy ${ }^{4}$
}

1. Department of Poultry Science, Madras Veterinary College, Chennai, Tamil Nadu, India; 2. Director of Distance Education, Madhavaram Milk Colony, Tamil Nadu Veterinary and Animal Sciences University, Chennai, Tamil Nadu, India; 3. Department of Poultry Science, Livestock Research Complex, Tamil Nadu Veterinary and Animal Sciences University, Orthanadu, Thanjavur, Tamil Nadu, India; 4. Department of Pharmacology, Veterinary University Training and Research

Centre, Tamil Nadu Veterinary and Animal Sciences University, Thanjavur, Tamil Nadu, India.

Corresponding author: Darshana B. Bhaisare, e-mail: darshanabhaisare@gmail.com,

DT: drthyagu2002@yahoo.com, RRC: drchurchil@yahoo.com, NP: murthyvcri@hotmail.com

Received: 26-08-2014, Revised: 09-10-2014, Accepted: 14-10-2014, Published online: 12-11-2014

doi: 10.14202/vetworld.2014.938-942. How to cite this article: Bhaisare DB, Thyagarajan D, Churchil RR, Punniamurthy $N$ (2014) Effect of dietary supplementation of herbal seeds on carcass traits of turkey poults, Veterinary World 7(11): $938-942$.

\section{Abstract}

Aim: The present study was conducted to find the effect of four herbal seeds on carcass traits of turkey poults.

Materials and Methods: A biological study using Nandanam turkey poults (Meleagris gallapavo) for 8 weeks duration was carried out to evaluate the effect of phytobiotics-containing four herbal seeds influence on production performances like biweekly body weight and on carcass traits. 150 poults were randomly subjected to five dietary treatments in a completely randomized design with basal diet (T1), $0.5 \%$ (5 g/kg) level of each seeds thyme (Thymus vulgaris) (T2), fenugreek (Trigonella foenum graecum) (T3), fennel (Foeniculum vulgare) (T4) and cumin (Cuminum cyminum) (T5). Carcass traits like blood loss, feather loss, dressed weight, New York dressed weight, ready to cook yield and cut-up parts yield were studied.

Results: The body weight at $8^{\text {th }}$ week was higher $(\mathrm{p}<0.05)$ in poults fed with thyme; whereas at $6^{\text {th }}$ week, fennel and cumin fed birds had better $(\mathrm{p}<0.05)$ body weight. Inclusion of herbal seeds did not affect the blood loss, dressed weight and ready to cook yield but it significantly $(\mathrm{p}<0.05)$ affected the feathered loss, New York dressed weight and giblet percentages. Feeding of fenugreek has improved New York dressed weight of poults. Feeding of fennel had depressive $(p<0.05)$ effect on liver and gizzard weights. All the four phytobiotic seeds in feed had significant $(\mathrm{p}<0.05)$ reduction in breast weight with a compensatory improvement in drumstick and neck weights.

Conclusion: The present study revealed that supplementation of phytobiotic herbal seeds has resulted in numerical improvement of body weight of poults throughout the study period whereas these seeds had negative effect on the yield of breast, with increased proportion of drumstick and neck.

Keywords: carcass traits, cumin, fennel, fenugreek, phytobiotics, thyme, turkey.

\section{Introduction}

Antibiotic as the growth promoter in the poultry industry has been seriously criticized by governmental policy makers and consumers since the development of antibiotic resistance through poultry products with potential harm on human health [1]. Recognizing that antibiotic-resistance poses such a serious health threat, the European Union has totally banned the use of growth promoting antibiotics in animal feed [2]. In July 1997, the European Union banned four antibiotic growth promoters (tylosin, spiramycin, bacitracin and virginiamycin). In December 1997, the European Union banned the animal growth-promoter avoparcin in all its member states [3]. In India, the antibiotics are being used widely in food animals as growth promoters and to prevent and treat infectious diseases [4]. Currently there are no regulatory provisions regarding the use of antibiotics in livestock and poultry. The ban of antibiotics in animal feeds

Copyright: The authors. This article is an open access article licensed under the terms of the Creative Commons Attributin License (http:// creative commons.org/licenses/by/2.0) which permits unrestricted use, distribution and reproduction in any medium, provided the work is properly cited. has consequences in the international trade of poultry meat because the European Union allow imports of foods of antibiotic residue free products only. During the last two decades, considerable research has been done in exploring the beneficial effects of the growth promoters and identifying suitable alternative to antibiotics [5]. A wide variety of substances are now being used in conjunction with or as alternatives to antibiotic growth promoters in poultry diets [6]. There is an urgent need to find out the efficacies of these substances as an alternative to antibiotic growth promoters as feed additives. Researches showed that pre and probiotics $[7,8]$ symbiotic, organic acids, different enzymatic preparates and also different extracts (aqueous, hydro alcoholic, oils, essential oils) [9] from medicinal and aromatic plants can be considered as potential growth promoters.

Phytobiotic preparations are the preparations of vegetative origin containing chemical constituents, which positively affect the micro flora of the digestive system [10]. It is related to the anti-oxidative inhibition [11] stimulation of the detoxicative enzymes, cell functions, binding of the excess substances and the 
intestinal microflora. Some of the beneficial effects of phytobiotics include increament in feed intake, stimulation of digestive secretions, stimulation of immune system, antimicrobial, antioxidant and coccidiostatic activity, pharmacological actions such as laxative, spasmolytic and astringent effects as well as prevention of flatulence and denaturizing. Now consequent to the increasing concern about the potential public health problems due to antibiotic resistance, poultry nutritionists are being challenged to develop an alternative for antibiotic growth promoters [1]. Several studies indicated that these feed additives could be used in poultry ration as antifungal, antibacterial and antioxidant compounds [12]. Phytobiotics provides potential alternative to the antibiotic usage.

By keeping the above facts in view, this study has been taken up to study and compare the effect of feeding certain herbal seeds as phytobiotics on production performance and carcass traits in turkey poults.

\section{Materials and Methods}

\section{Ethical approval}

Study was carried out after permission from the Institutional Animal Ethics Committee.

\section{Biological experiment}

A biological experiment of 8 weeks duration was conducted in turkey poults to find out the effect of four herbal seeds namely thyme (Thymus vulgaris), fenugreek (Trigonella foenum graecum), fennel (Foeniculum vulgare) and cumin (Cuminum cyminum) as phytobiotics on carcass traits. A total number of 150 straight run day old turkey poults of nandanam turkey variety belonging to a single hatch were utilised for the study. The poults were weighed individually, and wing banded. They were randomly divided into five treatment groups with three replicates of 10 poults each. The experimental birds were reared under identical management conditions up to 8 weeks of age. Mean body weight was recorded between 0 and 8 weeks at biweekly intervals. The dietary treatments included the basal diet as control (T1), supplemented experimental groups each receiving $5 \mathrm{~g} / \mathrm{kg}(0.5 \%)$ thyme seeds (T2) or fenugreek seeds (T3) or fennel seeds (T4) or cumin seeds (T5) added to the basal diet. These experimental feeds were fed to the respective treatment groups ad libitum from 0 to 8 weeks of age. At the end of every fortnight, body weight was recorded. The hydroalcoholic extract of above selected seeds were analysed for comparative studies on the presence of various phyto-constituents according to methods given by Sofowora, 1994 [13].

\section{Carcass characteristics}

At the end of $8^{\text {th }}$ week of age, six poults (three male and three females) from each treatment were taken randomly for the carcass study. After bleeding and defeathering, head and shanks were removed. New York dressed weight and dressed weight was estimated. The organ weights of heart, liver and gizzard and total intestinal length were recorded. Eviscerated carcass with giblets was weighed to determine readyto-cook yield. Each carcass was cut into its parts namely breast, thighs, drumsticks, wings, back and necked and weighed separately.

\section{Statistical analysis}

The means were compared by one-way ANOVA for significant differences among treatments using SPSS software (version 7.5). The percentage data were converted into arc sin values before statistical analysis.

\section{Results and Discussion}

The addition of phytobiotic herbal seeds in the diet had significant effect in body weight at the end of second $(p<0.01)$, third $(p<0.05)$ and fourth $(p<0.05)$ fortnights (Table-1). The turkey poults receiving fenugreek and fennel in diet weighed more $(\mathrm{p}<0.05)$ at second and third fortnights. At the end of the experiment, turkey poults receiving thyme attained significantly $(\mathrm{p}<0.05)$ higher body weight than control, while fenugreek, fennel and thyme seeds fed birds had intermediary body weights which were statistically similar to that of control and thyme fed poults. In general, supplementation of phytobiotic seeds has resulted in numerical improvement of body weight of poults throughout the study period. Positive impact on body weight could be due to the positive effect of certain phytobiotic chemicals like phenol, flavonoids and saponins on gut health [14]. This could also be due to improving efficiency in digestion and assimilation. Many earlier studies on thyme [15] fenugreek [16] and fennel [17] supported the findings of our experiment. However, contradictory results of no effect of herbal seeds on growth rate has also been reported in the literature [18].

The incorporation of phytobiotic herbal seeds in the feed of turkey poults did not alter blood loss, dressed weight and ready to cook yield whereas there was significant $(\mathrm{p}<0.05)$ difference observed in feather loss, New York dressed weight and giblets percentages among different treatment groups (Table-2). Dietary supplementation of phytobiotic herbal seeds did not show significant change in percentages of heart, back, wing and thigh but liver, gizzard, breast, drumstick and neck percentages were significantly $(\mathrm{p}<0.05)$ different among treatments (Table-3).

\section{Thyme ( $T$. vulgaris)}

The results indicated that none of the carcass trait was altered by the feeding of thyme. However, breast cut-up part showed a significant $(p<0.05)$ decrease but drumstick and neck had significant $(\mathrm{p}<0.05)$ improvement over the control by feeding of thyme. The increased yield could be due to the metabolic role of essential and volatile oils included in thyme seeds. In a partial agreement with present results Rahim et al. (2011) [19] reported that inclusion of alcoholic extract of thyme at $0.2,0.4$ and $0.6 \%$ in drinking water 
Table-1: Effect of phytobiotics-containing herbal seeds as feed supplements on overall body weight (g) at fortnight in turkey poults.

\begin{tabular}{lcccc}
\hline Treatments & \multicolumn{4}{c}{ Fortnights } \\
\cline { 2 - 5 } & I ( $\mathbf{0 - 2}$ weeks) & I I (3-4 weeks) & I I I (5-6 weeks) & I V (7-8 weeks) \\
\hline T1 & $128.34 \pm 2.98(30)$ & $191.09^{\mathrm{c}} \pm 6.00(29)$ & $471.01^{\mathrm{b}} \pm 15.01(29)$ & $807.14^{\mathrm{b}} \pm 36.75(28)$ \\
T2 & $133.55 \pm 3.60(30)$ & $209.71^{\mathrm{bc}} \pm 10.83(28)$ & $521.86^{\mathrm{ab}} \pm 19.69(27)$ & $915.00^{\mathrm{a}} \pm 31.66(26)$ \\
T3 & $132.21 \pm 3.41(30)$ & $237.86^{\mathrm{a}} \pm 10.75(28)$ & $549.04^{\mathrm{a}} \pm 22.01(28)$ & $868.92^{\mathrm{ab}} \pm 35.02(28)$ \\
T4 & $136.01 \pm 3.51(30)$ & $228.94^{\mathrm{ab}} \pm 6.79(30)$ & $533.66^{\mathrm{a}} \pm 21.97(30)$ & $865.14^{\mathrm{ab}} \pm 30.32(30)$ \\
T5 & $129.97 \pm 2.76(30)$ & $209.61^{\mathrm{bc}} \pm 7.94(30)$ & $514.82^{\mathrm{ab}} \pm 18.23(30)$ & $863.67^{\mathrm{ab}} \pm 35.79(30)$ \\
F value & $0.885^{\mathrm{NS}}$ & $4.422^{* *}$ & $2.215^{*}$ & $1.205^{*}$ \\
\hline
\end{tabular}

Mean values within a column sharing a common superscript are not statistically different $(p>0.05)$,

NS $=$ Non-significant $(p>0.05), * p<0.05, * * p<0.01$, The figures in parentheses indicate number of observations

Table-2: Effect of phytobiotics-containing herbal seeds as feed supplements on carcass traits (\%) at $8^{\text {th }}$ week of age in turkey poults $(n=6)$.

\begin{tabular}{|c|c|c|c|c|c|c|}
\hline Treatments & $\begin{array}{l}\text { Blood } \\
\text { loss }\end{array}$ & $\begin{array}{l}\text { Feather } \\
\text { loss }\end{array}$ & $\begin{array}{c}\text { New York } \\
\text { dressed weight }\end{array}$ & $\begin{array}{l}\text { Dressed } \\
\text { weight }\end{array}$ & Giblets & $\begin{array}{l}\text { Ready to } \\
\text { cook yield }\end{array}$ \\
\hline $\mathrm{T} 1$ & $4.12 \pm 0.02$ & $7.80^{\mathrm{ab}} \pm 0.01$ & $88.08^{b} \pm 0.01$ & $65.18 \pm 0.00$ & $4.97^{\mathrm{ab}} \pm 0.01$ & $70.16 \pm 0.00$ \\
\hline $\mathrm{T} 2$ & $2.88 \pm 0.02$ & $8.47^{\mathrm{ab}} \pm 0.01$ & $88.64^{\mathrm{ab}} \pm 0.01$ & $67.03 \pm 0.01$ & $4.85^{\mathrm{ab}} \pm 0.00$ & $71.88 \pm 0.01$ \\
\hline T3 & $2.99 \pm 0.01$ & $5.60^{\mathrm{b}} \pm 0.03$ & $91.41^{\mathrm{a}} \pm 0.02$ & $67.65 \pm 0.02$ & $5.27^{\mathrm{a}} \pm 0.01$ & $72.93 \pm 0.02$ \\
\hline T4 & $3.99 \pm 0.02$ & $6.37^{\mathrm{ab}} \pm 0.02$ & $89.65^{\mathrm{ab}} \pm 0.02$ & $68.8 \pm 0.02$ & $4.27^{b} \pm 0.00$ & $73.08 \pm 0.02$ \\
\hline T5 & $3.06 \pm 0.02$ & $8.65^{a} \pm 0.02$ & $88.30^{b} \pm 0.01$ & $67.04 \pm 0.01$ & $4.81^{\mathrm{ab}} \pm 0.00$ & $71.85 \pm 0.01$ \\
\hline F value & $0.787^{\mathrm{NS}}$ & $1.898 *$ & $2.121 *$ & $1.045^{\mathrm{NS}}$ & $2.569 *$ & $0.856^{\mathrm{NS}}$ \\
\hline
\end{tabular}

a,b Means within column bearing different superscripts differ significantly $(p<0.05)$, * Significant $(p<0.05)$, NS $=$ Non-significant $(p>0.05)$

increased relative weights of breast and wing ( $\mathrm{p} \leq 0.05)$. However, no evidence of quadratic effects among carcass weight, dressing percentage, liver weight, giblet percentage due to dietary supplementation of thyme observed in earlier studies [20,15]. In contrast to the findings of the present study, increased weight by Navid and Myandoab (2011) [21] and no change by Isa (2011) [22] on breast yield of broilers at 1.5 and $0.04 \%$ dietary levels were recorded respectively. However, by feeding $0.1 \%$ thyme in drinking water, Rahimi et al. (2011) [23] observed negative effect on relative weights of carcass, which is different from the results of the present study. The stimulatory effects of carvacrol in thyme on pancreatic secretions by increasing the secretions of digestive enzymes resulting in better assimilation could be attributed to changes observed in certain carcass traits [24].

\section{Fenugreek (T. graecum)}

The dietary inclusion of Fenugreek seeds in the feed has resulted in significant $(\mathrm{p}<0.05)$ improvement in New York dressed weight compared to control. In terms of cut-up parts, significant $(\mathrm{p}<0.05)$ decrease in breast cut and increased $(\mathrm{p}<0.05)$ drumstick and neck percentage due to fenugreek feeding. The antimicrobial and antibiotics like properties of fenugreek [25] might be ascribed as the reason for better dressing percentage and variations in certain cut-up parts. At a lower level of $0.3 \%$ inclusion the non-significant difference observed by Abbas (2010) [18] on carcass characteristics like heart, liver, gizzard weight on liver was consistent to the results of present study but inconsistent to the, decreased dressing percentage of the present study. The results of the present study was confirmed by Khan et al. (2009) [26] who observed insignificant difference in liver weight by feeding 10 , 20 and $30 \mathrm{ml} / \mathrm{L}$ aqueous extract of fenugreek seed on broiler chicks. However, in contrast to the earlier observations of no significant difference recorded by Alloui et al. (2012) [16] whereas the current study showed improvement at similar inclusion level.

\section{Fennel (F. vulgare)}

Fennel at $0.5 \%$ level in feed had no influence on any of the carcass characteristics in comparison to control. However, the organ weights of liver and gizzard were significantly $(p<0.05)$ low due to the feeding of fennel. The cut-up part study revealed significant decrease in breast cut with compensatory increase $(p<0.05)$ in drumstick and neck cuts of the poults. The results of the present study were confirmed by Abdullah and Rabia (2009) [17] and denoted that addition of 1,2 and $3 \mathrm{~g} / \mathrm{kg}$ fennel seeds to the broiler diets resulted in no significant differences in all carcass characteristic. These results could be due to the presence of phytochemicals such as phenols, saponins and flavonoids [27] in fennel seeds that have relative effects on carcass traits.

\section{Cumin (C. cyminum)}

Feeding of cumin at $0.5 \%$ level in the feed of turkey poults has not affected any of the carcass characters, whereas, cut-up parts study showed depressive $(p<0.05)$ effect of dietary cumin on the breast with significant $(\mathrm{p}<0.05)$ improvement on the drumstick and neck weights. These positive effects might be due to the presence of some bioactive principles [28] in cumin seeds that are responsible for an increase on carcass weights. 


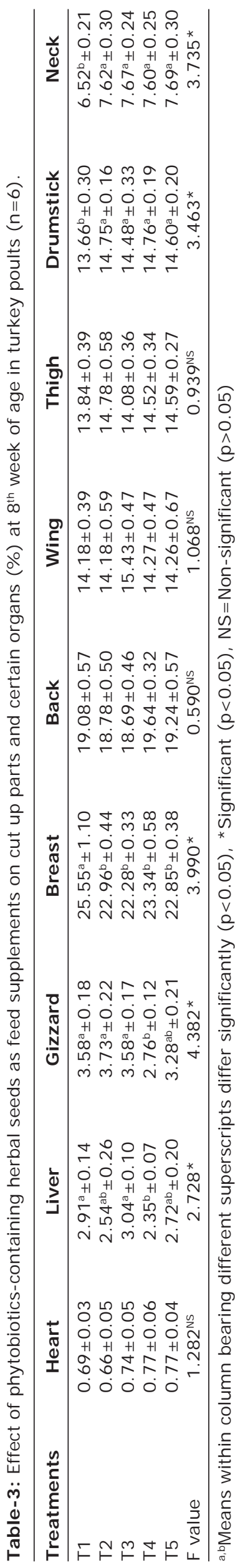

\section{Conclusion}

Among all four herbal seeds, supplementation of thyme seeds in feed of turkey poults showed better performance in terms of body weight. The present study revealed that feed supplementation of phytobiotic herbal seed has no favourable effect on carcass yield and carcass characteristics. On the other hand, feeding of all the four herbal seeds had a negative effect on the yield of breast, a valuable cut of the carcass with an increased proportion of less priced cuts like drumstick and neck. Therefore, it may be concluded that the usage of herbal seeds as phytobiotic should be carefully decided based on their merit on other production parameters.

\section{Authors' Contributions}

DT and NP have designed a plan of work. DBB carried out the laboratory work. DT and RRC supervised the research. RRC helped with the statistical analysis. DT and RRC drafted and revised the manuscript. All authors read and approved the final manuscript.

\section{Acknowledgments}

The financial support and facilities provided by the Tamil Nadu Veterinary and Animal Sciences University, Chennai, India are duly acknowledged. The authors are thankful to the Dean of Madras Veterinary College and Dr. A.V. Omprakash, Head of Institute of Poultry Production and Management, Tamil Nadu Veterinary and Animal Sciences University, Chennai-600 051, India for providing necessary facilities to carry out research work.

\section{Competing I nterests} interests.

The authors declare that they have no competing

\section{References}

1. William, P. and Losa, R. (2001) The use of essential oils and their compounds in poultry nutrition. World Poult., 17(4): $14-15$.

2. Gilbert, N. (2012) Rules tighten on use of antibiotics on farms. Nature, 481: 7380.

3. Castanon, J.I.R. (2007) Review history of the use of antibiotic as growth promoters in European poultry feeds. Poult. Sci., 86: 2466-2471.

4. Van, H.J., Puister-Jansen, L.F., Van Asselt, E.D., Burgers, S.L. (2011) Farm factors associated with the use of antibiotics in pig production. J. Anim. Sci., 89: 1922-1929.

5. Toghyani, M., Toghyani, M., Gheisari, A., Chalamkari, G. and Mohammadrezaei, M. (2010) Growth performance, serum biochemistry and blood hematology of broiler chicks fed different levels of black seed (Nigella sativa) and peppermint (Mentha piperita). Livest. Sci. 129: 173-178.

6. Windisch, W., Schedle, K., Plitzner, C. and Kroismayr, A. (2008) Use of phytogenic products as feed additives for swine and poultry. J. Anim. Sci., 86: 140-148.

7. Gupta, A.R. and Das, S. (2013) The benefits of probiotics in poultry production: an overview. Int. J. Livest. Res., 3(1): 18-22.

8. Alloui, M.N., Szczurek, W. and Swiątkiewicz, S. (2013) The usefulness of prebiotics and probiotics in modern poultry nutrition: a review. Ann. Anim. Sci., 13(1): 17-32. 
9. Gopi, M., Karthik, K., Manjun Athachar, H.V., Tamilmahan, P., Kesavan, M., Dashprakash, M., Balaraju, B.L. and Purushothaman, M.R. (2014) Essential oils as a feed additive in poultry nutrition. Adv. Anim. Vet. Sci., 2(1): 1-7.

10. Eevuri, T.R. and Putturu, R. (2013) Use of certain herbal preparations in broiler feeds - A review. Vet, World, 6(3): 172-179.

11. Wei, A. and Shibamoto, T. (2007) Antioxidant activities and volatile constituents of various essential oils. J. Agric. Food Chem., 55: 1737-1742.

12. Khosravi, A. Boldaji, F. Dastar, B. and Hasani, S. (2008) The use of some feed additives as growth promoter in broilers nutrition. Int. J. Poult. Sci., 7(11): 1095-1099.

13. Sofowora, E.A. (1994) Medicinal Plants and Traditional Medicine in Africa. John Wiley and Sons Ltd., New York.

14. Yadav, R., Tiwari, R., Chowdhary, P., Pradhan, C. (2011) A pharmacognostical monograph of Trigonella foenum-graecum seeds. Int. J. Pharm. Sci., 3(5): 442-445.

15. Navid, H.M. and Nezhady, M.M. (2011) The effect of using thyme, garlic and nettle on performance, carcass quality and blood parameters. Ann. Biol. Res., 2(4): 315-320.

16. Alloui, N., Aksa, B.S., Alloui, M.N. and Ibrir, F. (2012) Utilization of fenugreek (Trigonella foenum-graecum) as growth promoter for broiler chickens. J. World Poult. Res., 2(2): 25-27.

17. Abdullah, A.M. and Rabia, J.A. (2009) The effect of using fennel seeds (Foeniculum vulgare 1 .) on productive performance of broiler chickens. Int. J. Poult. Sci., 8(7): 642-644.

18. Abbas, R.J. (2010) Effects of using fenugreek, parsley and sweet basil seeds as feed additives on the performance of broiler chickens. Int. J. Poult. Sci., 9(3): 278-282.

19. Rahim, A., Aghazadeh, A.M. and Daneshyar, M. (2011) Growth performance and some carcass characteristics in broiler chickens supplemented with thymus extract (Thymus vulgaris) in drinking water. J. Am. Sci., 7(11): 400-405.

20. Wareth, A.A.A. (2011) Effect of thyme, oregano and their major active components on performance and intestinal microbial populations of broilers. Dissertation of Doctor of Agricultural Science (Dr. Agr.) Submitted to Rheinische Friedrich-Wilhelms University, Bonn, Germany, p67. http:// www.hss.ulb.uni-bonn.de/2011/2527/2527.pdf. Accessed on 01-10-2014.

21. Navid, H.M. and Myandoab, M.P. (2011) The effects of different levels of Thyme on performance, carcass traits, blood parameters of broilers. Ann. Biol. Res., 2(4): 379-385.

22. Isa, J.A.A. (2011) Performance and lipid profile of broilers fed two medicinal plant. http://www.scholar.najah.edu/publication/thesis . Accessed on 02-10-2014.

23. Rahimi, S., Zadeh, Z.T., Torshizi1, M.A.K., Omidbaigi, R. and Rokni, H. (2011) Effect of the three herbal extracts on growth performance, immune system, blood factors and intestinal selected bacterial population in broiler chickens. J. Agric. Sci. Technol., 13: 527-539.

24. Lee, K.W., Everts, H. and Beyen, A.C. (2003). Dietary carvacrol lowers body gain but improves feed conversion in female broiler chickens. J. Appl. Poult. Res., 12: 394-399.

25. Dash, B.K., Sultana, S. and Sultana, N. (2011) Antibacterial activities of methanol and acetone extracts of fenugreek (Trigonella foenum) and coriander (Coriandrum sativum). Life Sci. Med. Res., 27: 1-8.

26. Khan, F.U., Durrani, F.R., Sultan, A., Khan, R.U. and Naz, S. (2009) Effect of fenugreek (Trigonella foenum-graecum) seed extract on visceral organs of broiler chicks. J. Agric. Biol. Sci., 4(1): 58-60.

27. Mandegary, A., Pournamdari, M., Sharififar, F., Pournourmohammadi, S., Fardiar, R. and Shooli, S. (2012) Alkaloid and flavonoid rich fractions of fenugreek seeds (Trigonella-foenum-graecum L.) with antinociceptive and anti-inflammatory effects. Food Chem. Toxicol., 50: 2503-2507.

28. Madhukar, C. (2013) Phytochemical screening of cumin seeds extract. Rep. Opin., 5(1): 57-58. 